\title{
PENGARUH TINGKAT KESEHATAN BANK TERHADAP RETURN SAHAM BANK BUMN PERIODE 2009-2018
}

\author{
Tahmat \\ tahmatdj@gmail.com \\ Ida Margareta Nainggolan \\ Universitas Sangga Buana Yayasan Pendidikan Keuangan dan Perbankan
}

\begin{abstract}
An Assessment of rate bank health using a risk-based banking rating shows a bank's performance in a certain period, investors who invest in the capital market will be interested in stocks with good bank performance. This study aims to determine the effect of bank soundness on stock returns listed on the Indonesia Stock Exchange of the periode 2009-2018. This study analyzes the bank's health rate consisting of NPL (Non Performing Loan), LDR (Loan to Deposit Ratio), ROA (Return On Asset), NIM (Net Interest Margin) and CAR (Capital Adequacy Ratio). This research uses quantitative methods with descriptive and associative approaches. The results of the research with a descriptive approach show that all ratios of the Bank's Health Rate are in accordance with Bank Indonesia regulations. The results of the study with an associative approach showed that the LDR (Loan to Deposit Ratio) had a significant effect on stock returns, while the NPL (Non Performing Loan), ROA (Return On Asset), NIM (Net Interest Margin) and CAR (Capital Adequacy Ratio) partially no significant effect on stock returns. The variable dimensions on the level of bank health simultaneously have a significant effect on BUMN bank stock returns of the periode 2009-2018.
\end{abstract}

Key words: bank's health rate; stock return

\begin{abstract}
ABSTRAK
Penilaian tingkat kesehatan bank dengan menggunakan pendekatan risiko (Risk Based Banking Rating) menunjukkan kinerja suatu bank pada periode tertentu, investor yang melakukan investasi di pasar modal akan tertarik pada saham dengan kinerja bank yang baik. Penelitian ini bertujuan untuk mengetahui pengaruh tingkat kesehatan bank terhadap return saham yang terdaftar di Bursa Efek Indonesia periode 2009-2018. Penelitian ini menganalisa tingkat kesehatan bank yang terdiri dari NPL (Non Performing Loan), LDR (Loan to Deposit Ratio), ROA (Return On Asset), NIM (Net Interest Margin) dan CAR (Capital Adequacy Ratio). Penelitian ini menggunakan metode kuantitatif dengan pendekatan deskriptif dan asosiatif. Hasil penelitian dengan pendekatan deskriptif menunjukkan bahwa semua rasio tingkat kesehatan bank yang diteliti telah sesuai dengan ketentuan Bank Indonesia. Hasil penelitian dengan pendekatan asosiatif menunjukkan bahwa LDR (Loan to Deposit Ratio) berpengaruh signifikan terhadap return saham, sedangkan NPL (Non Performing Loan), ROA (Return On Asset), NIM (Net Interest Margin) dan CAR (Capital Adequacy Ratio) secara parsial tidak berpengaruh signifikan terhadap return saham. Dimensi variabel pada tingkat kesehatan bank secara simultan berpengaruh signifikan terhadap return saham bank BUMN pada periode 2009-2018.
\end{abstract}

Kata kunci: tingkat kesehatan bank; return saham

\section{PENDAHULUAN}

Kemajuan teknologi pada revolusi industri 4.0 memberikan dampak positif bagi kemajuan pasar modal Indonesia. Saat ini perdagangan berbasis elektronik dan aplikasi (e-commerce) berkembang sangat pesat. Perkembangan layanan financial technology (fintech) akan membuat akses yang mudah dan cepat bagi masyarakat yang ingin berinvestasi di pasar modal. Berdasarkan data PT Kustodian Sentral Efek Indonesia (KSEI) per 19 November 2018, 
kenaikan jumlah investor saham di pasar modal dalam hal ini adalah Bursa Efek Indonesia (BEI) telah mencapai 31,97\% dibandingkan jumlah investor yang tercatat akhir 2017. Tahun 2019, BEI telah mencapai target yang telah ditetapkan yaitu mencapai 150ribu investor saham yang baru. Data per Agustus 2019, jumlah investor yang aktif melakukan transaksi setiap bulan meningkat $32 \%$ dari rata-rata investor yang aktif tahun lalu mencapai 178.000 .

Peningkatan jumlah investor di pasar modal membuktikan bahwa ketertarikan masyarakat untuk berinvestasi di pasar modal. Pasar modal menjalankan fungsi sebagai sarana penghubung antara investor yang memiliki dana dengan perusahaan atau institusi lainnya yang membutuhkan dana. Investasi dalam berbagai investasi keuangan dapat diperdagangkan di bursa efek dengan tujuan untuk menyebarkan sumber perolehan (return) dan kemungkinan risiko. Kemungkinan risiko pada investasi di pasar modal adalah risiko sistematis (Systemic Risk) yang merupakan risiko yang dapat mengakibatkan perubahan permintaan dan penawaran saham sehingga menyebabkan perubahan pada harga saham di pasar modal. Salah satu risiko sistematis adalah tingkat inflasi.

Pada tahun 2012, PT. Bursa Efek Indonesia (BEI) bekerjasama dengan PT. Infoarta Pratama (penerbit majalah Infobank) meluncurkan indeks saham Infobank15 yang berisikan 15 saham-saham perbankan yang memiliki kinerja positif di Bursa Efek Indonesia dengan tujuan mempermudah investor dan pelaku pasar dalam memantau pergerakannya. Laju pergerakan saham perbankan (Infobank15) masih tercatat positif yang naik sebesar $5,90 \%$ years to date (YTD), dibandingkan dengan IHSG dan LQ45 yang mengalami penurunan sebesar $0,04 \%$ dan $0,83 \%$ years to date (YTD). Jika dilihat dari aktivitas transaksi Bank BUMN, saat ini 3 dari 4 Bank BUMN (BBNI, BBRI dan BMRI) terdaftar sebagai Top Market Capital, Top Trading Value dan Top Trading Frequency. Perbandingan harga saham Bank BUMN dengan tingkat inflasi periode 2009-2018, perkembangan harga saham Bank BUMN dapat menutupi tingkat inflasi. Kenaikan harga saham pada bank BUMN yaitu: BBNI sebesar 369\% dengan rata-rata kenaikan pertahun $36,9 \%$, BBRI sebesar $341 \%$ dengan rata-rata kenaikan per tahun $34,1 \%$, BBTN sebesar $215 \%$ dengan rata-rata kenaikan per tahun $21,5 \%$ dan BMRI sebesar $207 \%$ dengan rata-rata kenaikan per tahun 20,7\% dibandingkan dengan rata-rata inflasi per tahunnya sebesar $4,77 \%$.

Investor membutuhkan informasi kesehatan perusahaan melalui perbandingan antara modal sendiri dan modal pinjaman. Perusahaan yang memiliki modal sendiri yang lebih besar daripada modal pinjaman berarti sehat dan tidak mudah bangkrut. Sesuai dengan Peraturan Otoritas Jasa Keuangan nomor 4/POJK.03/2016 tentang Penilaian Tingkat Kesehatan Bank Umum (2016). Bank wajib melakukan penilaian tingkat kesehatan bank secara individu dengan menggunakan pendekatan risiko (Risk-Based Banking Rating) dengan cakupan penilaian terhadap faktor RGEC (Risk Profile, Good Coorporate Governance, Earnings, Capital). Dengan kinerja bank yang baik akan menarik minat investor untuk melakukan investasi di sektor perbankan. Apabila perbankan yang mengeluarkan saham dengan kondisi kinerja yang baik, harga saham akan cenderung meningkat, sehingga diharapkan bisa memberikan return sesuai dengan harapan investor.

Berdasarkan latar belakang tersebut maka peneliti tertarik untuk meneliti tentang "Pengaruh Tingkat Kesehatan Bank Terhadap Return Saham (Studi Kasus Pada Bank BUMN Yang Terdaftar Di Bursa Efek Indonesia) Periode 2009-2018."

Pembatasan masalah dalam penelitian ini mengenai pengaruh tingkat kesehatan bank pada laporan keuangan hanya dengan menggunakan 3 (tiga) faktor penilaian dalam menganalisa tingkat kesehatan bank, meliputi faktor Risk Profile (Profil Risiko) dengan NPL (Non Performing Loan) dan LDR 
(Loan to Deposit Ratio), faktor Earnings (Rentabilitas) dengan ROA (Return On Asset) dan NIM (Net Interest Margin) serta faktor Capital (Permodalan) dengan CAR (Capital Adequacy Ratio). Faktor GCG (Good Coorporate Governance) tidak dianalisa karena menyangkut kerahasiaan bank. Penelitian ini menggunakan data laporan keuangan pada periode 2009-2018 sehingga diharapkan mampu memberikan hasil yang lebih aktual dan akurat.

Berdasarkan latar belakang yang telah diuraikan sebelumnya maka dapat dirumuskan masalah sebagai berikut: (1) Bagaimana perkembangan tingkat kesehatan bank yang terdiri dari NPL (Non Performing Loan), LDR (Loan to Deposit rasio), ROA (Return On Asset), NIM (Net Interest Margin) dan CAR (Capital Adequacy Ratio) pada Bank BUMN Periode 2009-2018; (2) Bagaimana perkembangan return saham pada Bank BUMN Periode 2009-2018; (3) Bagaimana pengaruh tingkat kesehatan bank yang terdiri dari rasio NPL (Non Performing Loan), LDR (Loan to Deposit Rasio), ROA (Return On Asset), NIM (Net Interest Margin) dan CAR (Capital Adequacy Ratio) baik secara parsial maupun simultan terhadap return saham Bank BUMN Periode 2009-2018.

Tujuan dari penelitian yang peneliti lakukan adalah: (1) Mengetahui, mendeskripsikan dan menganalisa perkembangan tingkat kesehatan bank yang terdiri dari NPL (Non Performing Loan), LDR (Loan to Deposit Rasio), ROA (Return On Asset), NIM (Net Interest Margin) dan CAR (Capital Adequacy Ratio) pada Bank BUMN Periode 2009-2018; (2) Mengetahui, mendeskripsikan dan menganalisa perkembangan return saham pada Bank BUMN Periode 20092018; (3) Mengukur pengaruh tingkat kesehatan bank yang terdiri dari NPL (Non Performing Loan), LDR (Loan to Deposit Rasio), ROA (Return On Asset), NIM (Net Interest Margin) dan CAR (Capital Adequacy Ratio) baik secara parsial maupun simultan terhadap return saham Bank BUMN Periode 2009-2018.

\section{TINJAUAN TEORETIS}

Return merupakan keuntungan yang diperoleh oleh perusahaan, individu dan institusi dari hasil kebijakan investasi yang dilakukan. Faktor-faktor yang mempengaruhi return saham adalah kinerja perusahaan. Kinerja bank yang baik akan menarik minat investor untuk melakukan invetasi di sektor perbankan. Apabila perbankan yang mengeluarkan saham dengan kondisi kinerja yang baik, harga saham akan cenderung meningkat, sehingga diharapkan bisa memberikan return sesuai dengan harapan investor (Dewi dan Prameswari, 2018: 150).

Menurut Ikatan Bankir Indonesia (2016) menjelaskan bahwa tingkat kesehatan bank merupakan hasil penilaian atas berbagai aspek yang berpengaruh terhadap kondisi atau kinerja suatu bank. Penilaian terhadap faktor-faktor tersebut dilakukan melalui penilaian secara kuantitatif setelah mempertimbangkan unsur judgment yang didasarkan atas materialitas dari faktor-faktor penilaian, serta pengaruh dari faktor lain seperti kondisi industri perbankan dan perekonomian. Faktor-faktor penilaian tingkat kesehatan bank terdiri atas pengukuran atas profil risiko (Risk Profile), tata kelola perusahaan yang baik (Good Corporate Governance), penilaian rentabilitas (Earnings) dan penilaian permodalan (Capital).

Menurut penelitian Hafidhin et al. (2018: 116), menyatakan bahwa PT Bank Mandiri (Persero) Tbk, selaku Bank milik pemerintah yang memiliki aset terbesar, diukur berdasarkan rasio NPL, LDR, ROA, NIM dan CAR mendapatkan Peringkat Komposit 1 dengan predikat "sangat sehat". Hal tersebut mencerminkan kondisi PT. Bank Mandiri (Persero) Tbk. yang dinilai sangat mampu menghadapi pengaruh negatif yang signifikan dari perubahan kondisi bisnis dan faktor eksternal lainnya, 
namun apabila terjadi kelemahan maka dapat dikatakan secara umum kelemahan tersebut tidak signifikan.

Menurut penelitian Naftali et al. (2018: 2498), menyatakan bahwa GCG, ROA, dan CAR berpengaruh signifikan terhadap Harga Saham. Risk Profile tidak berpengaruh signifikan terhadap Harga Saham. Sedangkan uji simultan menunjukkan bahwa Tingkat kesehatan bank yaitu RGEC berpengaruh signifikan terhadap Harga Saham. Dalam hal ini perusahaan sebaiknya tetap meningkatkan kinerjanya agar bank tetap berada pada posisi yang sehat, sehingga bisa menarik banyak investor untuk berinvestasi.

Menurut penelitian Widyanigrum et al. (2014: 1) menyatakan bahwa Return On Asset menunjukkan masih terdapat bank yang tidak sehat dengan nilai Return On Asset di bawah 1,25\%. Penilaian Net Interest Margin menunjukkan keseluruhan bank yang menjadi sampel penelitian dapat digolongkan ke dalam bank sehat. Penilaian terhadap faktor capital dengan rasio Capital Adequacy Ratio menunjukkan hasil yang positif pada setiap bank, secara keseluruhan setiap bank memiliki nilai Capital Adequacy Ratio di atas $10 \%$ sehingga masuk ke dalam bank sehat.

Menurut penelitian Paputungan (2016), menyatakan bahwa Hasil analisis menunjukkan bahwa kinerja keuangan pada PT. Bank Rakyat Indonesia cabang Manado untuk Rasio CAR, KAP, PPAP, NPM, ROA, BOPO, LDR dikategorikan dalam kelompok sehat.

Menurut penelitian Wijaya (2018), menyatakan bahwa ada beberapa bank yang memiliki "Kurang Sehat", "Cukup Sehat", "Cukup Bagus". Bank Mandiri, BRI dan BNI menerima predikat "Cukup Bagus" dalam faktor profil risiko untuk risiko likuiditas, sedangkan Bank BTN menerima predikat "Cukup Sehat". Selain itu, Bank BTN menerima predikat "Cukup Sehat" dan "Cukup Bagus" dalam faktor laba khususnya faktor ROA dan GCG. Menurut penelitian Hermuningsih (2013), menyatakan bahwa variabel profitabilitas, growth opportunity dan struktur modal, berpengaruh positif dan signifikan terhadap nilai perusahaan. Ini berarti, semakin besar profitabilitas, semakin tinggi peluang pertumbuhan, dan semakin besar proporsi hutang dalam struktur pendanaan perusahaan, maka semakin besar pula nilai perusahaan tersebut. Kedua, variabel struktur modal merupakan variabel intervening bagi growth opportunity dan tidak bagi profitabilitas. Yang terakhir ini disebabkan karena profitabilitas memiliki pengaruh yang berlawanan dengan struktur modal. Ini berarti, struktur modal akan memperbesar pengaruh positif profitabilitas perusahaan terhadap nilai perusahaan tersebut.

Menurut penelitian Wuryandani et al. (2014: 264) menyatakan bahwa Kurang kuatnya pengaruh kebijakan moneter, mengindikasikan bahwa Bank Indonesia tidak perlu menyerap likuiditas melalui suku bunga Bank Indonesia yang tinggi, mengingat likuiditas bank lebih ditentukan oleh kondisi operasional, permodalan, kondisi sistem keuangan, dan makroekonomi.

Menurut penelitian Uzliawati et al. (2014: 201) menyatakan bahwa likuiditas perbankan yang terdaftar di BEI tidak terlalu dipertimbangkan pihak eksternal perusahaan dalam melakukan penilaian sebuah perbankan. Sehingga likuiditas tidak memiliki pengaruh terhadap nilai perusahaan perbankan.

Menurut penelitian Kellen (2011) menyatakan bahwa makin tingkat nilai profitabilitas maka makin tinggi nilai perusahaan dan makin tinggi tingkat risko berpengaruh positif tetapi tidak signifikan terhadap nilai perusahaan.

Menurut penelitian Ahmad (2015) menyatakan bahwa CAR memiliki pengaruh negatif namun tidak signifikan terhadap ROA. LDR memiliki pengaruh positif namun tidak signifikan terhadap ROA. BOPO dan NPL memiliki pengaruh negatif namun signifikan terhadap ROA. NIM memiliki pengaruh positif namun signifikan 
terhadap ROA. Menurut penelitian Pradana dan Sanjaya (2017: 122) menyatakan bahwa profitabilitas merupakan variabel utama yang masuk dalam pertimbangan RUPS untuk menentukan keputusan pembagian dividen tunai. Semakin tinggi profitabilitas (ROA), semakin besar pula probabilitas perbankan akan membagikan dividen tunai.

Menurut penelitian Suhardjanto dan Dewi (2011: 115) menyatakan bahwa mekanisme tata kelola perusahaan dan profitabilitas yang mencukupi menjadikan perusahaan mendapatkan keuntungan positif, yaitu mendapatkan kepercayaan dari masyarakat yang pada akhirnya akan berdampak meningkatnya keuntungan perusahaan di masa yang akan datang. Menurut penelitian Subandi dan Ghozali (2013: 133) menyatakan bahwa variabel yang mempengaruhi kinerja profitabilitas ROA perbankan konvensional, yang paling lemah pengaruhnya adalah LDR.

\section{METODE PENELITIAN}

Metode yang digunakan dalam penelitian ini adalah kuantitatif dengan pendekatan deskriptif dan asosiatif. Metode kuantitatif dapat diartikan sebagai metode penelitian yang berlandaskan pada filsafat positivisme, digunakan untuk meneliti pada populasi atau sampel tertentu, pegumpulan data menggunakan instrumen penelitian, analisis data bersifat kuantitatif atau statistik, dengan tujuan untuk menggambarkan dan menguji hipotesis yang ditetapkan. Tingkat Eksplanasi yang digunakan dalam penelitian ini adalah penelitian deskriptif dan asosiatif. Penelitian deskriptif bertujuan untuk menggambarkan keadaan atau nilai satu atau lebih variabel secara mandiri. Sedangkan penelitian asosiatif bertujuan untuk menggambarkan dan menguji hipotesis hubungan dua variabel atau lebih.

\section{Populasi dan Sampel Penelitian}

Populasi dalam penelitian ini adalah 90 perusahaan sektor finance yang terdaftar di Bursa Efek Indonesia (BEI). Jumlah emiten di sektor finance yang masuk dalam index papan utama sebanyak 47 perusahaan sedangkan yang masuk dalam index pengembangan sebanyak 43 perusahaan.

Teknik pengambilan sampel untuk menentukan sampel yang akan digunakan dalam penelitian ini adalah Nonprobability Sampling dengan pendekatan purposive sampling. Teknik pengambilan sampel yang tidak memberi peluang atau kesempatan sama bagi setiap unsur atau anggota populasi untuk dipilih menjadi sampel dengan pertimbangan tertentu. Berdasarkan pertimbangan tertentu maka sampel yang digunakan dalam penelitian ini adalah 4 (empat) bank BUMN.

\section{Teknik Pengumpulan Data}

Pengumpulan data yang dilakukan dalam penelitian ini berdasarkan sumbernya menggunakan data sekunder. Jenis data yang digunakan dalam penelitian ini berupa rasio keuangan yang terdapat pada laporan keuangan dan annual report yang dipublikasikan dalam masing-masing situs bank.

\section{Operasionalisasi Variabel Penelitian}

Variabel dalam penelitian ini adalah Variabel independen adalah tingkat kesehatan bank $(X)$, sedangkan variabel dependen adalah return saham (Y). Operasionalisasi variabel menyajikan konsep variabel secara umum serta keterangan-keterangan lain mengenai indikator, ukuran dan skala pengukuran variabel.

\section{Tingkat Kesehatan Bank (X)}

Tingkat Kesehatan Bank (variabel X) merupakan hasil penilaian atas aspek risk profile, earning dan capital. Dimensi dari Tingkat Kesehatan Bank $(X)$ adalah sebagai berikut:

1. Rasio NPL (Non Performing Loan) adalah perbandingan antara seluruh kredit pada pihak ketiga dengan kolektibilitas kurang lancar, diragukan dan macet dengan total kredit. 
2. Rasio LDR (Loan to Deposit Ratio) adalah perbandingan total kredit dengan dana pihak ketiga.

3. Rasio ROA (Return On Assets), adalah perbandingan laba bersih dengan ratarata total asset.

4. Rasio NIM (Net Interest Margin) adalah perbangingan pendapatan bunga dari kredit, investasi, dikurangi biaya dana deposito, tabungan dan sebagainya dengan rata-rata bagi debit aktiva produktif.

5. Rasio CAR (Capital Adequacy Ratio), adalah perbandingan antara total modal dengan total aktiva tertimbang menurut risiko.

\section{Return Saham (Y)}

Return Saham (variabel Y) adalah tingkat pengembalian yang diterima oleh seorang investor dari saham yang diperdagangkan di pasar modal, yang dihitung dari selisih harga jual saham.

\section{Teknik Analisis Data Analisis Deskriptif}

Penelitian ini menggunakan analisis deskriptif untuk menganalisa data dengan cara mendeskripsikan dan menggambarkan data sebagai berikut:

1. Menganalisa perkembangan tingkat kesehatan bank yang terdiri dari NPL (Non Performing Loan), LDR (Loan to Deposit Ratio), ROA (Return On Asset), NIM (Net Interest Margin) dan CAR (Capital Adequacy Ratio) pada bank BUMN periode 2009-2018.

2. Menganalisa perkembangan return saham bank BUMN selama periode 20092018.

\section{Analisis Asosiatif}

Pengujian hipotesis asosiatif atau hubungan dalam penelitian ini menggunakan analisis regresi data panel, bertujuan untuk melakukan prediksi, bagaimana perubahan nilai variabel dependen bila nilai variabel independen dinaikkan atau diturunkan nilainya (dimanipulasi).

\section{Analisis Regresi Data Panel}

Penelitian ini menggunakan data kuantitatif dengan analisis regresi data panel yaitu kombinasi data time series dan cross section dengan mengunakan Software Olah Data E-views.

\section{Uji Asumsi Klasik}

Uji asumsi klasik digunakan untuk menguji model regresi yang digunakan dalam penelitian ini layak diuji atau tidak. Pengujian asumsi klasik dilakukan setelah model regresi diestimasi, bukan sebelum model regresi diestimasi. Dikarenakan pengujian asumsi klasik yang meliputi normalitas, autokorelasi, multikorelasitas dan heteroskedastisitas membutuhkan data residual model yang didapat setelah model terbentuk. Uji asumsi klasik digunakan untuk memastikan bahwa normalitas, autokorelasi, multikolinearitas dan heteroskedastisitas tidak terdapat dalam model yang digunakan. Jika keseluruhan syarat tersebut terpenuhi, berarti bahwa model analisis telah layak digunakan.

\section{Pengujian Hipotesis}

Pengujian hipotesis dalam penelitian ini mengunakan Uji $t$ (Uji regresi secara parsil), Uji F (Uji regresi secara simultan) dan Koefisien determinasi.

\section{ANALISIS DAN PEMBAHASAN \\ Analisis Deskriptif}

Perkembangan Tingkat Kesehatan Bank pada PT. Bank Negara Indonesia Tbk

PT. Bank Negara Indonesia Tbk adalah sebuah institusi bank milik negara, dan merupakan bank komersial tertua dalam sejarah Republik Indonesia. Bank ini didirikan pada tanggal 5 Juli 1946. Kinerja PT. Bank Negara Indonesia Tbk didukung dengan penyaluran kredit yang paling dominan di sektor agribisnis, selain itu terdapat sektor lainnya seperti telekomunikasi, industri kimia, konstruksi, kelistrikan, minyak gas, pertambangan, perdagangan besar dan eceran. Berdasarkan Tabel 1 perkembangan tingkat kesehatan bank pada PT. Bank Negara Indonesia Tbk, maka dapat disimpulkan sebagai berikut: 
Tabel 1

Perkembangan Tingkat Kesehatan Bank pada PT. Bank Negara Indonesia Tbk

\begin{tabular}{llllll}
\hline Tahun & NPL & LDR & ROA & NIM & CAR \\
\hline 2009 & $4,68 \%$ & $64,60 \%$ & $1,72 \%$ & $6,01 \%$ & $13,78 \%$ \\
2010 & $4,28 \%$ & $70,15 \%$ & $2,49 \%$ & $5,78 \%$ & $18,63 \%$ \\
2011 & $3,61 \%$ & $70,37 \%$ & $2,94 \%$ & $6,03 \%$ & $17,63 \%$ \\
2012 & $2,84 \%$ & $77,52 \%$ & $2,92 \%$ & $5,93 \%$ & $16,67 \%$ \\
2013 & $2,17 \%$ & $85,30 \%$ & $3,36 \%$ & $6,11 \%$ & $15,09 \%$ \\
2014 & $1,96 \%$ & $87,81 \%$ & $3,49 \%$ & $6,20 \%$ & $16,22 \%$ \\
2015 & $2,70 \%$ & $87,77 \%$ & $2,64 \%$ & $6,42 \%$ & $19,49 \%$ \\
2016 & $2,96 \%$ & $90,41 \%$ & $2,69 \%$ & $6,17 \%$ & $19,36 \%$ \\
2017 & $2,26 \%$ & $85,58 \%$ & $2,75 \%$ & $5,50 \%$ & $18,53 \%$ \\
2018 & $1,90 \%$ & $88,76 \%$ & $2,78 \%$ & $5,29 \%$ & $18,51 \%$ \\
Max & $4,68 \%$ & $90,41 \%$ & $3,49 \%$ & $6,42 \%$ & $19,49 \%$ \\
Min & $1,90 \%$ & $64,06 \%$ & $1,72 \%$ & $5,29 \%$ & $13,78 \%$ \\
Rata-rata & $2,94 \%$ & $80,77 \%$ & $2,78 \%$ & $5,94 \%$ & $17,39 \%$ \\
\hline
\end{tabular}

Sumber: Olahan Data Eviews versi 10, 2019

\section{a. Rasio NPL (Non Performing Loan)}

Pencapaian rasio NPL (Non Performing Loan) tertinggi pada tahun 2009, dikarenakan krisis subprime mortgage 2008 (krisis sektor perumahan). Krisis ini berawal dari krisis keuangan disebabkan produk derivatif, berkembangan ke krisis perbankan kemudian menjadi krisis ekonomi. Perekonomian Indonesia juga terkena imbas dari krisis ini dikarenakan dana pembangunan yang bersumber dari utang luar negeri, industri yang berbasis ekspor, tidak memberikan perlindungan bagi industri dalam negeri. Kondisi ekonomi yang melemah pada 2008 tersebut, sehingga pada tahun 2009 terjadi peningkatan kredit bermasalah.

Pencapaian rasio NPL (Non Performing Loan) terendah pada tahun 2018, dikarenakan pertumbuhan kredit yang optimal dengan memaksimalkan program pemerintah (KUR) sebagai basis pertumbuhan. Selain itu, untuk mendukung pencapaian kredit segmen kecil terdapat penambahan channel yaitu agen 46 dan penyaluran kredit berbasis digital untuk mempermudah pengajuan kredit. Pertumbuhan kredit tersebut dilakukan dengan prinsip kehati-hatian sehingga rasio NPL (Non Performing Loan) dapat terjaga.

\section{b. Rasio LDR (Loan to Deposit Rasio)}

Pencapaian rasio LDR (Loan to Deposit Ratio) tertinggi pada tahun 2016, dikarenakan pertumbuhan kredit industri perbankan yang lebih tinggi daripada pertumbuhan simpanan nasabah, BNI menyadari bahwa salah satu kendala yang dihadapi adalah pertumbuhan Dana Pihak Ketiga yang belum optimal dalam mendukung pertumbuhan kredit dengan tingkat volatilitas yang masih tinggi. Dalam rangka mengatasi kendala tersebut, BNI telah menetapkan strategi dalam meningkatkan DPK melalui closedloop transaction dan transaksi e-channel. Pengembangan digital banking untuk meningkatkan customer experience, transaksi dan penjualan.

Pencapaian rasio LDR (Loan to Deposit Ratio) terendah pada tahun 2009, dikarenakan BNI lebih memilih menjaga kualitas kreditnya daripada ekspansi kredit. Dalam mempertahankan kualitas kreditnya, BNI akan membentuk unit kontrol kredit dan membentuk posisi Regional Collection Manager yang bertanggung jawab atas kualitas kredit di 
kantor cabang, serta akan membangun Collection and Recover Management System (CMS) sebagai alat monitor kegiatan bagi unit Regional Collection.

c. Rasio ROA (Return On Asset)

Pencapaian rasio ROA (Return On Asset) tertinggi pada tahun 2014, dikarenakan keberhasilan pencapaian kebijakan strategis terkait sinergi antara segmen Business Banking dan Consumer dan Retail Banking diarahkan melalui value chain dan supply chain dengan mengoptimalkan nasabah corporate sehingga dapat meningkatkan pemanfaatan produk (product usage) dan transaksi nasabah (customer transaction).

Pencapaian rasio ROA (Return On Asset) terendah pada tahun 2009, dikarenakan BNI lebih memilih menjaga kualitas kreditnya daripada ekspansi kredit. Fokus BNI terhadap perbaikan kualitas pada kredit bermasalah membuat pencapaian laba tidak maksimal.

\section{d. Rasio NIM (Net Interest Margin)}

Pencapaian rasio NIM (Net Interest Margin) tertinggi pada tahun 2015, dikarenakan pertumbuhan kredit segmen korporasi (termasuk pinjaman luar negeri) sebesar 21,3\%. Fokus ekspansi kredit segmen korporasi adalah BUMN dan korporasi lokal maupun multinasional di sektor-sektor prioritas seperti infrastruktur (telekomunikasi, jalan tol dan kontruksi, kelistrikan, minyak dan gas serta transportasi), manufaktur, perdagangan dan perkebunan.

Pencapaian rasio NIM (Net Interest Margin) terendah pada tahun 2018, dikarenakan salah satu strategi BNI untuk dapat menjaga kualitas aset dengan tidak menaikkan suku bunga pinjaman yang diberikan selama tahun 2018 walaupun Bank Indonesia telah menaikkan suku bunga acuannya dari 4,25\% di awal tahun 2018 menjadi 6,00\% pada penutupan tahun 2018.

\section{e. Rasio CAR (Capital Adequacy Ratio)}

Pencapaian rasio CAR (Capital Adequacy Ratio) tertinggi pada tahun 2015, dikarenakan adanya pelaksanaan revaluasi 380ndus tetap yang dilakukan tanggal 30 September 2015 dan telah mendapatkan persetujuan Direktur Jendral Pajak. Hasil revaluasi 8 industri tersebut, nilai buku 8 industri tetap BNI secara keseluruhan meningkat sebesar Rp 12,3 triliun.

Pencapaian rasio CAR (Capital Adequacy Ratio) terendah pada tahun 2009, namun masih di atas ketentuan regulator sebesar $8 \%$. Tingkat kecukupan modal tersebut masih memungkinkan bagi BNI untuk mengembangkan usaha kedepannya.

\section{Perkembangan Tingkat Kesehatan Bank pada PT. Bank Rakyat Indonesia Tbk}

PT. Bank Rakyat Indonesia Tbk adalah salah satu bank milik pemerintah terbesar di Indonesia berdiri tanggal 16 Desember 1895. Fokus utama menjadi penyedia layanan UMKM terdepan dan meraih keunggulan operasional melalui perbankan digital, serta terus mengembangkan kompetensi di sektor UMKM yang didukung teknologi terkini.

Tabel 2

Perkembangan Tingkat Kesehatan Bank pada PT. Bank Rakyat Indonesia Tbk

\begin{tabular}{llllll}
\hline \hline Tahun & NPL & LDR & ROA & NIM & CAR \\
\hline 2009 & $3,52 \%$ & $80,88 \%$ & $3,73 \%$ & $9,14 \%$ & $13,20 \%$ \\
2010 & $2,78 \%$ & $75,17 \%$ & $4,64 \%$ & $10,77 \%$ & $13,76 \%$ \\
2011 & $2,30 \%$ & $76,20 \%$ & $4,93 \%$ & $9,58 \%$ & $14,96 \%$ \\
2012 & $1,78 \%$ & $79,85 \%$ & $5,15 \%$ & $8,42 \%$ & $16,95 \%$ \\
2013 & $1,55 \%$ & $88,54 \%$ & $5,03 \%$ & $8,55 \%$ & $16,99 \%$ \\
2014 & $1,69 \%$ & $81,68 \%$ & $4,74 \%$ & $8,51 \%$ & $18,31 \%$ \\
2015 & $2,02 \%$ & $86,88 \%$ & $4,19 \%$ & $8,13 \%$ & $20,59 \%$ \\
2016 & $2,03 \%$ & $87,88 \%$ & $3,84 \%$ & $8,27 \%$ & $22,91 \%$ \\
2017 & $2,10 \%$ & $88,13 \%$ & $3,69 \%$ & $7,93 \%$ & $22,96 \%$ \\
2018 & $2.14 \%$ & $89,57 \%$ & $3,68 \%$ & $7,45 \%$ & $21,21 \%$ \\
Max & $3,52 \%$ & $89,57 \%$ & $5,15 \%$ & $10,77 \%$ & $22,96 \%$ \\
Min & $1,55 \%$ & $75,51 \%$ & $3,68 \%$ & $7,45 \%$ & $13,20 \%$ \\
Rata- & $2,91 \%$ & $83,48 \%$ & $4,36 \%$ & $8,67 \%$ & $18,18 \%$ \\
rata & & & & & \\
\hline Sumber & Olaban & &
\end{tabular}

Sumber: Olahan Data Eviews versi 10, 2019

Berdasarkan Tabel 2, perkembangan tingkat kesehatan bank pada PT. Bank 
Rakyat Indonesia Tbk diatas, maka dapat disimpulkan sebagai berikut:

\section{a. Rasio NPL (Non Performing Loan)}

Pencapaian rasio NPL (Non Performing Loan) tertinggi pada tahun 2009, dikarenakan krisis subprime mortgage 2008 (krisis sektor perumahan). Krisis ini berawal dari krisis keuangan disebabkan produk industry, berkembangan ke krisis perbankan kemudian menjadi krisis ekonomi. Perekonomian Indonesia juga terkena imbas dari krisis ini dikarenakan dana pembangunan yang bersumber dari utang luar negeri, industri yang berbasis ekspor, tidak memberikan perlindungan bagi 9 industri dalam negeri. Dampak dari krisis ekonomi terhadap bisnis pelanggan dan persaingan bisnis yang lebih ketat, untuk menurunkan rasio NPL (Non Performing Loan) telah dilakukan restrukturisasi atau pemulihan kredit masuk termasuk hapus buku pinjaman telah dilakukan secara maksimal.

Pencapaian rasio NPL (Non Performing Loan) terendah pada tahun 2013, dikarenakan upaya revitalisasi, cross selling antara produk segmen bisnis dan trickle down bisnis korporasi dengan segmen UMKM, serta pencapaian strategi lain yaitu perbaikan kualitas kredit di seluruh segmen bisnis. Pertumbuhan kredit nasional dengan disertai penurunan rasio NPL (Non Performing Loan) menunjukkan keberhasilan BRI dalam mengelola portofolio kredit yang sehat dan berkualitas.

\section{b. Rasio LDR (Loan to Deposit Rasio)}

Pencapaian rasio LDR (Loan to Deposit Rasio) tertinggi pada tahun 2018, peningkatan rasio LDR (Loan to Deposit Rasio) menunjukkan fungsi intermediasi dijalankan dengan baik untuk mendorong pertumbuhan ekonomi.

Rasio LDR (Loan to Deposit Rasio) tersebut berada pada kisaran target LDR BRI yaitu $90 \%+/-2 \%$ yang merupakan level optimal untuk menjaga profitabilitas BRI.
Pencapaian rasio LDR (Loan to Deposit Rasio) terendah pada tahun 2010. Upaya yang dilakukan BRI dalam mengontrol eksposur dan konsentrasi likuiditas dengan benar serta mengelola harian likuiditas, BRI akan melakukan pengelolaan terhadap batas risiko likuiditas.

\section{c. Rasio ROA (Return On Asset)}

Pencapaian rasio ROA (Return On Asset) tertinggi pada tahun 2012, dikarenakan kenaikan pendapatan dan biaya operasional yang terkendali.

Pencapaian rasio ROA (Return On Asset) terendah pada tahun 2018, dikarenakan perekonomian yang kurang kondusif seperti salah satu kebijakan Amerika Serikat terkait pemberlakuan Tariff dagang, penurunan tingkat pajak atau biasa disebut dengan Trump's Tax Reform akan menarik banyak investor untuk melakukan investasi di Amerika serikat (Pajak penghasilan perusahaan dari 35\% menjadi 21\%). Akibat tekanan dari penguatan dollar AS membuat nilai tukar rupiah mengalami depresiasi pada kuartal II 2018. Hal tersebut membuat lesunya indutri pembiayaan nasional.

d. Rasio NIM (Net Interest Margin)

Pencapaian rasio NIM (Net Interest Margin) tertinggi pada tahun 2010, dikarenakan peningkatan produktivitas pinjaman dan dampak implementasi Standar Pelaporan Keuangan (Penyataan Standar Akuntansi Keuangan/PSAK) No. 50/55, dimana perhitungan pendapatan bunga dengan tingkat bunga tetap dikonversi ke tingkat bunga efektif.

Pencapaian rasio NIM (Net Interest Margin) terendah pada tahun 2018, dikarenakan naiknya beban bunga sebagai dampak kenaikan suku bunga acuan BIRate sebanyak 175 bps pada tahun 2018.

\section{e. Rasio CAR (Capital Adequacy Ratio)}

Pencapaian rasio CAR (Capital Adequacy Ratio) tertinggi pada tahun 2017, dimana BRI dapat melakukan ekspansi bisnisnya sehingga mampu melindungi dari risiko solvabilitas. 
Pencapaian rasio CAR (Capital Adequacy Ratio) terendah pada tahun tahun 2009, namun masih diatas ketentuan regulasi $(8 \%)$.

\section{Perkembangan Tingkat Kesehatan Bank pada PT. Bank Tabungan Negara Tbk}

PT. Bank Tabungan Negara Tbk adalah Badan Usaha Milik Negara Indonesia yang bergerak di jasa keuangan perbankan berdiri sejak tahun 1897. Sejarah Bank BTN mulai diukir kembali dengan ditunjuknya oleh Pemerintah Indonesia pada tanggal 29 Januari 1974 melalui Surat Menteri Keuangan RI No. B-49/MK/I/1974 sebagai wadah pembiayaan proyek perumahan untuk rakyat. Sejalan dengan tugas tersebut, maka mulai tahun 1976 mulailah realisasi KPR (Kredit Pemilikan Rumah) pertama kalinya oleh Bank BTN di Indonesia.

Tabel 3

Perkembangan Tingkat Kesehatan Bank pada PT. Bank Tabungan Negara Tbk

\begin{tabular}{llllll}
\hline \hline Tahun & NPL & LDR & ROA & NIM & CAR \\
\hline 2009 & $3,38 \%$ & $101,29 \%$ & $1,47 \%$ & $4,60 \%$ & $21,49 \%$ \\
2010 & $3,26 \%$ & $108,42 \%$ & $2,05 \%$ & $5,93 \%$ & $16,74 \%$ \\
2011 & $2,75 \%$ & $102.56 \%$ & $2,03 \%$ & $5,76 \%$ & $15,03 \%$ \\
2012 & $4,09 \%$ & $100,90 \%$ & $1,94 \%$ & $5,83 \%$ & $17,69 \%$ \\
2013 & $4,05 \%$ & $104,42 \%$ & $1,79 \%$ & $5,44 \%$ & $15,62 \%$ \\
2014 & $4,01 \%$ & $108,86 \%$ & $1,12 \%$ & 4,47 & $14,64 \%$ \\
2015 & $3,42 \%$ & $108,78 \%$ & $1,61 \%$ & $4,87 \%$ & $16,97 \%$ \\
2016 & $2,84 \%$ & $102,66 \%$ & $1,76 \%$ & $4,98 \%$ & $20,34 \%$ \\
2017 & $2,66 \%$ & $103,13 \%$ & $1,71 \%$ & $4,76 \%$ & $18,87 \%$ \\
2018 & $2,82 \%$ & $103,13 \%$ & $1,34 \%$ & $4,32 \%$ & $18,21 \%$ \\
Max & $4,09 \%$ & $108,86 \%$ & $2,05 \%$ & $5,93 \%$ & $21,49 \%$ \\
Min & $2,66 \%$ & $100,90 \%$ & $1,12 \%$ & $4,32 \%$ & $14,64 \%$ \\
\hline Rata- & $3,33 \%$ & $104,43 \%$ & $1,68 \%$ & $5,10 \%$ & $17,56 \%$ \\
rata & & & & &
\end{tabular}

Sumber: Olahan Data Eviews versi 10, 2019

Berdasarkan Tabel 3, perkembangan tingkat kesehatan bank pada PT. Bank Tabungan Negara Tbk diatas, maka dapat disimpulkan sebagai berikut:

\section{a. Rasio NPL (Non Performing Loan)}

Pencapaian rasio NPL (Non Performing Loan) tertinggi pada tahun 2012, dikarenakan kredit perumahan bersubsidi dimana banyak debitur yang hanya membayar bunga di 2-3 tahun awal peminjaman namun ketika mendekati jatuh tempo debitur tidak mampu membayar pokok pinjaman dan bunga. Komite Asset dan Liability akan menetapkan langkah-langkah dalam perbaikan kualitas kredit tersebut.

Pencapaian rasio NPL (Non Performing Loan) terendah pada tahun 2017, dikarenakan BTN melakukan restrukturisasi beberapa rumah-rumah yang masih dihuni dan menawarkan penundaan pembayaran pokok selama 1 hingga 2 tahun kepada debitur. Langkah lainnya adalah dengan cara mempertahankan dan memastikan kualitas pinjaman yang disalurkan.

\section{b. Rasio LDR (Loan to Deposit Rasio)}

Pencapaian rasio LDR (Loan to Deposit Rasio) tertinggi pada tahun 2014. Berdasarkan formula rasio LDR (Loan to Deposit Rasio) yang ditetapkan Bank Indonesia (BI) tidak memasukkan komponen sumber pendanaan yang lain seperti obligasi, pinjaman berjangka waktu panjang dan sumber dana lainnya, sedangkan fokus BTN pada perumahan sehingga sebagian besar aset BTN merupakan kredit jangka panjang. Oleh karena itu, rasio LDR (Loan to Deposit Rasio) tidak sepenuhnya menggambarkan kondisi likuiditas BTN.

Pencapaian rasio LDR (Loan to Deposit Rasio) terendah pada tahun 2012, dikarenakan peningkatan simpanan sebagai sumber pembiayaan yang lebih tinggi dan peningkatan kredit sebagai aset. Namun pencapaiannya masih di atas ketentuan regulasi (maksimal 92\%).

\section{c. Rasio ROA (Return On Asset)}

Pencapaian rasio ROA (Return On Asset) tertinggi pada tahun 2010, dikarenakan peningkatan signifikan dari laba besih sebesar $86,75 \%$.

Pencapaian rasio ROA (Return On Asset) terendah pada tahun 2014, dikarenakan laba bersih tidak sesuai dengan target yang ditetapkan, akibat tingginya biaya bunga dan peningkatan 
Cadangan Kerugian Penurunan Nilai (CKPN).

\section{d. Rasio NIM (Net Interest Margin)}

Pencapaian rasio NIM (Net Interest Margin) tertinggi pada tahun 2010, dikarenakan BTN membuat strategi untuk menjaga rentabilitas, ketika menawarkan paket pembiayaan rumah (KPR) dengan tingkat bunga rendah dan terjangkau, BTN juga mengadakan diversifikasi portofolio pinjaman dan mengelola sumber pendanaan untuk melindungi margin bunga bersih.

Pencapaian rasio NIM (Net Interest Margin) terendah pada tahun 2018, dikarenakan Bank Indonesia mengubah arah kebijakan moneter serta menaikkan suku bunga kebijakan BI- rate 7 days reverse repo sebanyak 175 bps dari 4,25\% menjadi 6\% yang berdampak kenaikan biaya operasional.

\section{e. Rasio CAR (Capital Adequacy Ratio)}

Pencapaian rasio CAR (Capital Adequacy Ratio) tertinggi pada tahun 2009, dikarenakan IPO (penawaran saham perdana) di akhir tahun 2009 yang meningkatkan jumlah ekuitas secara signifikan.

Pencapaian rasio CAR (Capital Adequacy Ratio) terendah pada tahun 2014, namun masih diatas ketentuan regulasi $(8 \%)$.

\section{Perkembangan Tingkat Kesehatan Bank pada PT. Bank mandiri Tbk}

PT. Bank mandiri Tbk merupakan bank terbesar di Indonesia dalam hal aset, pinjaman dan deposit. Bank ini berdiri pada tanggal 2 Oktober 1998 sebagai bagian dari program restrukturisasi perbankan yang dilaksanakan oleh Pemerintahan Indonesia. Pada bulan Juli 1999, 4 bank milik pemerintah yaitu Bank Bumi Daya (BBD), Bank Dagang Negara (BDN), Bank Ekspor Impor Indonesia (Bank Exim) dan Bank Pembangunan Indonesia (Bapindo) digabungkan ke dalam Bank Mandiri. Sektor unggulan dalam penyaluran kredit adalah sektor transportasi, pergudangan, dan komunikasi.

Tabel 4

Perkembangan Tingkat Kesehatan Bank pada PT. Bank mandiri Tbk

\begin{tabular}{llllll}
\hline \hline Tahun & NPL & LDR & ROA & NIM & CAR \\
\hline 2009 & $2,62 \%$ & $59,15 \%$ & $3,13 \%$ & $5,19 \%$ & $15,43 \%$ \\
2010 & $2,21 \%$ & $65,44 \%$ & $3,63 \%$ & $5,39 \%$ & $13,36 \%$ \\
2011 & $2,18 \%$ & $71,65 \%$ & $3,37 \%$ & $5,29 \%$ & $15,34 \%$ \\
2012 & $1,74 \%$ & $77,66 \%$ & $3,55 \%$ & $5,58 \%$ & $15,48 \%$ \\
2013 & $1,60 \%$ & $82,97 \%$ & $3,66 \%$ & $5,68 \%$ & $14,93 \%$ \\
2014 & $1,66 \%$ & $82,02 \%$ & $3,57 \%$ & $5,94 \%$ & $16,60 \%$ \\
2015 & $2,29 \%$ & $87,05 \%$ & $3,15 \%$ & $5,90 \%$ & $18,60 \%$ \\
2016 & $3,96 \%$ & $85,86 \%$ & $1,95 \%$ & $6,29 \%$ & $21,36 \%$ \\
2017 & $3,45 \%$ & $88,11 \%$ & $2,72 \%$ & $5,63 \%$ & $21,64 \%$ \\
2018 & $2,79 \%$ & $96,74 \%$ & $3,17 \%$ & $5,52 \%$ & $20,96 \%$ \\
Max & $3,96 \%$ & $96,74 \%$ & $3,66 \%$ & $6,29 \%$ & $21,64 \%$ \\
Min & $1,60 \%$ & $59,15 \%$ & $1,95 \%$ & $5,19 \%$ & $13,36 \%$ \\
\hline Rata- & $2,45 \%$ & $79,66 \%$ & $3,19 \%$ & $5,64 \%$ & $17,37 \%$ \\
rata & & & & & \\
\hline
\end{tabular}

Sumber: Olahan Data Eviews versi 10, 2019

Berdasarkan Tabel 4, perkembangan tingkat kesehatan bank pada PT. Bank Mandiri Tbk diatas, maka dapat disimpulkan sebagai berikut:

\section{a. Rasio NPL (Non Performing Loan)}

Pencapaian rasio NPL (Non Performing Loan) tertinggi pada tahun 2016, dikarenakan perekonomian global selama 2015 mulai dari perlambatan perekonomian China, penyesuaian suku acuan Amerika Serikat oleh Federal Reserve dan harga komoditas dan energi yang turun.

Pencapaian rasio rasio NPL (Non Performing Loan) terendah pada tahun 2013, dikarenakan berhasil melakukan recovery kredit hapus buku sebesar $\mathrm{Rp}$. 2,21 triliun.

b. Rasio LDR (Loan to Deposit Rasio)

Pencapaian rasio LDR (Loan to Deposit Rasio) tertinggi pada tahun 2018 disebabkan karena Bank Indonesia mengubah arah kebijakan moneter serta menaikkan suku bunga kebijakan BI- rate 7 days reverse repo sebanyak 175 bps dari $4,25 \%$ menjadi $6 \%$, hal ini dilakukan sebagai respon terhadap pelemahan nilai 
tukar rupiah dan melebarnya defisit neraca transaksi berjalan.

Pencapaian rasio LDR (Loan to Deposit Rasio) terendah pada tahun 2009, dikarenakan terdapat mislending bagi bank mandiri dimana terdapat unsur obligasi rekap yang di-reprofilling oleh pemerintah sehingga tidak bisa menjadikan obligasi rekap itu sebagai dana tunai yang bisa disalurkan menjadi pinjaman.

c. Rasio ROA (Return On Asset)

Pencapaian rasio ROA (Return On Asset) tertinggi pada tahun 2013, dikarenakan keberhasilan dalam menerapkan strategi efisiensi dan efektifitas kegiatan operasional, peningkatan kredit dan perluasan operasional.

Pencapaian rasio ROA (Return On Asset) terendah pada tahun 2016, dikarenakan melambatnya pertumbuhan kredit, dengan adanya penerapan kebijakan yang "prudent" dan penguatan fundamental yang selama ini telah dilakukan otoritas.

\section{d. Rasio NIM (Net Interest Margin)}

Pencapaian rasio NIM (Net Interest Margin) tertinggi pada tahun 2016, dikarenakan penerapan kebijakan pricing produk dana maupun kredit.

Pencapaian rasio NIM (Net Interest Margin) terendah pada tahun 2009, untuk meningkatkan rasio NIM (Net Interest Margin) yang rendah maka Bank mandiri membuat strategi dalam meningkatkan volume pinjaman seperti segmen mikro, pinjaman konsumen dan kartu kredit.

e. Rasio CAR (Capital Adequacy Ratio)

Pencapaian CAR (Capital Adequacy Ratio) tertinggi pada tahun 2017, kondisi ini mencerminkan daya tahan perbankan yang masih cukup tinggi dalam mengatasi tekanan dan gejolak perekonomian.

Pencapaian rasio CAR (Capital Adequacy Ratio) terendah pada tahun 2014, rasio tersebut masih lebih tinggi dibandingkan rasio minimal yang ditentukan regulator $(8 \%)$.

\section{Perkembangan Return Saham pada Bank BUMN}

Keputusan untuk membeli atau tidak membeli saham dapat didasarkan pada kinerja saham. Setiap keputusan investasi memiliki keterkaitan kuat dengan terjadinya return. Berikut Tabel 5 perkembangan return saham pada bank BUMN dengan periode 2009-2018.

Tabel 5

Perkembangan Return Saham BUMN

\begin{tabular}{lllll}
\hline Tahun & BBNI & BBRI & BBTN & BMRI \\
\hline 2009 & $191,01 \%$ & $67,18 \%$ & $0,00 \%$ & $132,14 \%$ \\
2010 & $106,45 \%$ & $37,25 \%$ & $95,42 \%$ & $38,30 \%$ \\
2011 & $-1,94 \%$ & $28,57 \%$ & $-26,25 \%$ & $5,60 \%$ \\
2012 & $-2,63 \%$ & $2,96 \%$ & $24,68 \%$ & $20,00 \%$ \\
2013 & $6,76 \%$ & $4,32 \%$ & $-40,00 \%$ & $-3,09 \%$ \\
2014 & $54,43 \%$ & $60,69 \%$ & $38,51 \%$ & $37,26 \%$ \\
2015 & $-18,20 \%$ & $-1,93 \%$ & $7,4 \%$ & $-14,15 \%$ \\
2016 & $10,72 \%$ & $2,19 \%$ & $34,36 \%$ & $25,14 \%$ \\
2017 & $79,19 \%$ & $40,90 \%$ & $105,17 \%$ & $14,04 \%$ \\
2018 & $-11,11 \%$ & $11,00 \%$ & $-28,85 \%$ & $12,00 \%$ \\
Max & & & & $191,01 \%$ \\
Min & & & & $-40,00 \%$ \\
\hline Rata-rata & & & $28,64 \%$ \\
\hline
\end{tabular}

Sumber: Olahan Data Eviews versi 10, 2019

Perkembangan return saham pada bank BUMN periode 2009-2018, dapat diketahui return saham pada PT. Bank Negara Indonesia Tbk tahun 2009 adalah return saham yang paling besar yaitu 191,01\%. Pada tahun 2013, PT. Bank Tabungan Negara Tbk memiliki rata-rata return terendah sebesar $-40 \%$. Hal ini menunjukkan hasil negatif karena harga saham PT. Bank Tabungan Negara Tbk selama periode 2009-2018 mengalami penurunan yang signifikan, disebabkan karena perekonomian negaranegara berkembang sedang menghadapi rencana Bank Sentral Amerika Serikat (The Fed) memulai pengurangan laju pembelian obligasinya. Kebijakan tersebut membuat negara-negara berkembang yang umumnya berada di kawasan Asia, harus bersiap kehilangan sumber aliran dana segar tak terkecuali Indonesia. Perekonomian Indo- 
nesia tahun 2013 diprakirakan hanya tumbuh sebesar $5,7 \%$ bila dibandingkan dengan pertumbuhan tahun 2012 sebesar 6,2\%. Penurunan pertumbuhan ekonomi 2013 tercatat pada terbatasnya pertumbuhan ekspor rill akibat melambatnya ekonomi global. Sisi permintaan domestik, partumbuhan investasi, khususnya non-bangunan juga melambat sementara itu konsumsi rumah tangga masih menjadi penggerak utama pertumbuhan. Selama tahun 2013, terdapat return saham PT Bank Mandiri Tbk yang juga mengalami penurunan sebesar3,09\%. Kedua bank BUMN lainnya, meskipun tidak mengalami penurunan, bank tersebut tidak mengalami kenaikan return saham yang signifikan. Rata-rata return saham pada bank BUMN yang terdaftar di Busa Efek Indonesia selama periode 20092018 hanya sebesar 28,64\%. Hal ini dikarenakan semua bank BUMN pernah menghasilkan return saham negatif, sehing- ga secara keseluruhan dapat berdampak penurunan pada rata-rata return saham.

\section{Analisis Asosiatif}

Penelitian ini menggunakan analisis asosiatif, dimana hipotesis asosiatif merupakan dugaan terhadap ada tidaknya hubungan secara signifikan antara tingkat kesehatan bank terhadap return saham pada bank BUMN pada periode 2009-2018.

\section{Analisis Regresi Data Panel}

Penelitian ini menggunakan data tingkat kesehatan bank sebagai variabel bebas (independent variable) yang terdiri dari NPL (Non Performing Loan), LDR (Loan to Deposit Ratio), ROA (Return On Asset), NIM (Net Interest Margin) dan CAR (Capital Adequacy Ratio) pada bank BUMN yang terdaftar di Bursa Efek Indonesia selama periode 2009-2018 sedangkan return saham sebagai variabel terikat (dependent variable).

\section{Tabel 6 \\ Hasil Analisis Regresi Data Panel - Common Effect Model}

Dependent Variable: $Y$

Method: Panel Least Squares

Date: 12/24/19 Time: 13:29

Sample: 20092018

Periods included: 10

Cross-sections included: 4

Total panel (balanced) observations: 40

\begin{tabular}{crrrc}
\hline \multicolumn{1}{c}{ Variable } & Coefficient & Std. Error & t-Statistic & Prob. \\
\hline C & 271.6883 & 124.2869 & 2.185977 & 0.0358 \\
X1 & -0.814877 & 16.65715 & -0.048921 & 0.9613 \\
X2 & -2.198016 & 0.778268 & -2.824241 & $\mathbf{0 . 0 0 7 9}$ \\
X3 & -32.14514 & 23.06376 & -1.393751 & 0.1724 \\
X4 & 12.02707 & 10.46843 & 1.148890 & 0.2586 \\
X5 & -1.652083 & 2.651957 & -0.622968 & 0.5375 \\
\hline R-squared & 0.303713 & Mean dependent var & 28.63900 \\
Adjusted R-squared & 0.201318 & S.D. dependent var & 46.86162 \\
S.E. of regression & 41.87976 & Akaike info criterion & 10.44496 \\
Sum squared resid & 59633.08 & Schwarz criterion & 10.69830 \\
Log likelihood & -202.8993 & Hannan-Quinn criter. & 10.53656 \\
F-statistic & 2.966093 & Durbin-Watson stat & 2.271505 \\
Prob(F-statistic) & 0.025070 & & \\
\hline
\end{tabular}

Sumber: Olahan Data Eviews versi 10, 2019 


\section{Estimasi Model Regresi Data Panel}

\section{a. Common Effect Model}

Berikut pendekatan Common Effect Model dengan menggunakan aplikasi Eviews: Dari hasil pendekatan Common Effect Model diatas, dapat diketahui bahwa hanya LDR (Loan to Deposit Ratio) yang berpengaruh signifikan secara statistik jika dilihat dari nilai probabilitasnya $(0,0079<0,05)$. NPL (Non Performing Loan), ROA (Return On Asset), NIM (Net Interest Margin) dan CAR (Capital Adequacy ratio) tidak berpengaruh signifikan karena nilai probabilitas masing-masing variabel lebih dari 0,05.

b. Fixed Effect Model

Berikut pendekatan Fixed Effect Model dengan menggunakan aplikasi Eviews: Dari hasil pendekatan Fixed Effect Model diatas, dapat diketahui bahwa hanya rasio LDR (Loan to Deposit Ratio) yang berpengaruh signifikan secara statistik jika dilihat dari nilai probabilitasnya $(0,0338<0,05)$. NPL (Non Performing Loan), ROA (Return On Asset), NIM (Net Interest Margin), dan CAR (Capital Adequacy ratio) tidak berpengaruh signifikan karena nilai probabilitas masing-masing variabel lebih dari 0,05.

c. Random Effect Model

Pendekatan dengan Random Effect Model tidak dapat dilakukan dikarenakan jumlah variabel lebih besar daripada jumlah subjek penelitian.

Tabel 7

Hasil Analisis Regresi Data Panel - Fixed Effect Model

Dependent Variable: Y

Method: Panel Least Squares

Date: 12/24/19 Time: 13:50

Sample: 20092018

Periods included: 10

Cross-sections included: 4

Total panel (balanced) observations: 40

\begin{tabular}{|c|c|c|c|c|}
\hline Variable & Coefficient & Std. Error & t-Statistic & Prob. \\
\hline $\mathrm{C}$ & 371.6787 & 160.7176 & 2.312619 & 0.0275 \\
\hline $\mathrm{X}_{1}$ & 1.297804 & 17.31171 & 0.074967 & 0.9407 \\
\hline$X_{2}$ & -2.573218 & 1.158554 & -2.221060 & 0.0338 \\
\hline$X_{3}$ & -30.19019 & 26.35288 & -1.145613 & 0.2607 \\
\hline $\mathrm{X}_{4}$ & 0.787315 & 15.97883 & 0.049272 & 0.9610 \\
\hline$X_{5}$ & -2.088713 & 3.618577 & -0.577219 & 0.5680 \\
\hline \multicolumn{5}{|c|}{ Effects Specification } \\
\hline \multicolumn{5}{|c|}{ Cross-section fixed (dummy variables) } \\
\hline R-squared & 0.331098 & \multirow{7}{*}{\multicolumn{2}{|c|}{$\begin{array}{l}\text { Mean dependent var } \\
\text { S.D. dependent var } \\
\text { Akaike info criterion } \\
\text { Schwarz criterion } \\
\text { Hannan-Quinncriter } \\
\text { Durbin-Watson stat }\end{array}$}} & 28.63900 \\
\hline Adjusted R-squared & 0.158478 & & & 46.86162 \\
\hline S.E. of regression & 42.98826 & & & 10.55484 \\
\hline Sum squared resid & 57287.71 & & & 10.93484 \\
\hline Log likelihood & -202.0968 & & & 10.69223 \\
\hline F-statistic & 1.918078 & & & 2.389476 \\
\hline Prob(F-statistic) & 0.092746 & & & \\
\hline
\end{tabular}

Sumber: Olahan Data Eviews versi 10, 2019 


\section{Pemilihan Model Terbaik}

Pendekatan model data panel yang telah diestimasi, kemudian dilakukan pemilihan model data panel yang terbaik. Menentukan Common Effect Model atau Fixed Effect Model yang paling terbaik digunakan dalam penelitian.

Terdapat 3 pengujian untuk pemilihan model terbaik pada data panel yaitu Uji FChow, Uji Haustman dan Uji Lagrange Multiflier (LM). Penelitian ini tidak dapat mengestimasi model Random Effect Model, sehingga Uji Haustman dan Uji Lagrange Multiflier (LM) tidak dapat dilakukan. Pemilihan model terbaik pada penelitian ini hanya menggunakan Uji F-Chow.

\section{Pemilihan Model menggunakan Uji F-} Chow
Uji F dapat digunakan untuk memilih teknik dengan model pooled least square (PLS) atau model fixed effect. Langkah ini biasa disebut dengan Uji $F$ terrestriksi (restricted f-test). Hasil perhitungan f-test dengan menggunakan restricted f-test adalah yang merupakan cara pemilihan model estimasi dalam data panel data antara metode FEM.

Hipotesis yang digunakan dalam pengujian pemilihan model FEM dan PLS adalah sebagai berikut:

$\mathrm{H}_{0} \quad$ : Model PLS (Restricted)

$\mathrm{H}_{1} \quad$ : Model Fixed Effect (Unrestricted)

Pengujian $\mathrm{F}$ terrestriksi dapat dilakukan dengan menggunakan Redundant Fixed Effect Test. Berikut ini adalah hasil uji FChow:

\section{Tabel 8 \\ Hasil Uji F - Chow}

Redundant Fixed Effects Tests

Equation: Untitled

Test cross-section fixed effects

\begin{tabular}{lcrl}
\hline Effects Test & Statistic & d.f. & Prob. \\
\hline Cross-section F & 0.423048 & $(3,31)$ & $\mathbf{0 . 7 3 7 8}$ \\
Cross-section Chi-square & 1.604971 & 3 & 0.6583 \\
\hline
\end{tabular}

Sumber: Olahan Data Eviews versi 10, 2019

Cara mengestimasi hasil redundant test adalah jika nilai probabilitas dari cross section $\mathrm{F}$ lebih kecil daripada nilai a $(0,05)$ yang digunakan, maka menerima $\mathrm{H}_{1}$ sehingga memilih metode FEM yang lebih tepat digunakan untuk model ini. Sedangkan apabila nilai probabilitas dari cross section $\mathrm{F}$ lebih besar daripada nilai a $(0,05)$ yang digunakan, maka menerima $\mathrm{H}_{0}$ sehingga memilih metode PLS lebih tepat digunakan untuk model ini. Hasil uji F-Chow menunjukkan bahwa nilai Prob.Cross-Section F $>$ nilai a $(0,05)$ dengan nilai Probabilitas 0,7378 > 0,05, maka memilih Common Effect Model yang tepat untuk penelitian ini. Berdasarkan hasil analisis regresidata panel pada Tabel 6, maka diperoleh persama- an regresi data panel sebagai berikut:
RS=271,69-0,815NPL-2,1980LDR-32,145ROA+12,027NIM$1,652 \mathrm{CAR}+\varepsilon$

Keterangan:

RS : Return Saham

NPL : Non Performing Loan

LDR : Loan to Deposit Ratio

ROA : Return On Asset

NIM : Net Interest Margin

CAR : Capital Adequacy Ratio

\section{Uji Asumsi Klasik}

Pengujian model regresi yang digunakan dalam penelitian ini layak diuji atau tidak. Pengujian asumsi klasik dilakukan setelah model regresi diestimasi, bukan sebelum model regresi diestimasi. Dikarenakan pengujian asumsi klasik yang meliputi normalitas, autokorelasi, multikorelasitas 
dan heteroskedastisitas membutuhkan data residual model yang didapat setelah model terbentuk.

\section{Uji Normalitas}

Uji asumsi normalitas dapat dilakukan salah satunya dengan menggunakan metode Jarque-Berra. Nilai statistik Jarque-Berra didasarkan pada chi-squares. Kriteria pengujiannya adalah:

$\mathrm{H}_{0}$ : Jarque-Berra $>$ Chi Square, $\mathrm{p}$-value $<$ $5 \%$, data tidak terdistribusi dengan normal

$\mathrm{H}_{1}$ : Jarque-Berra < Chi Square, $\mathrm{p}$-value $>$ $5 \%$, data terdistribusi dengan normal.

Berikut hasil uji normalitas pada Common Effect Model:

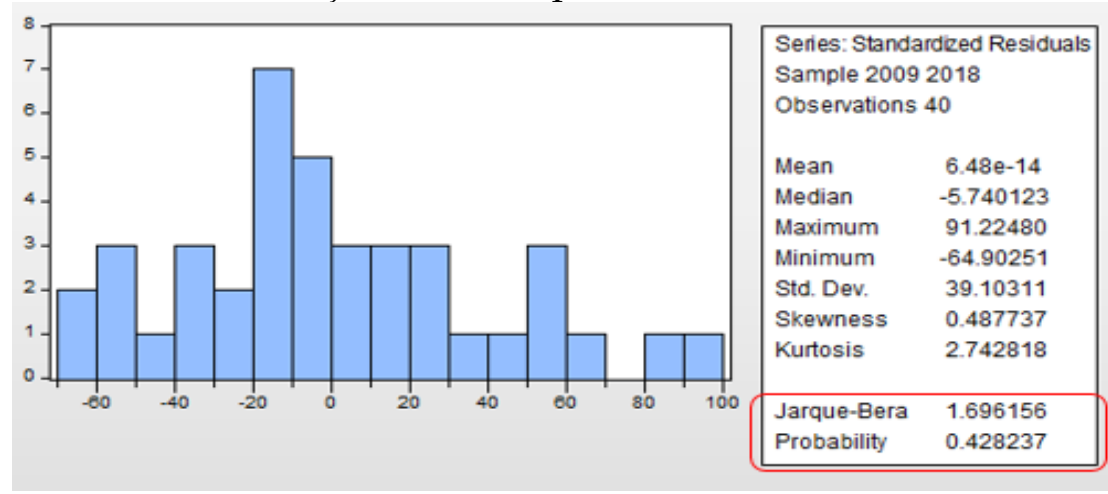

Gambar 1

Uji Normalitas

Sumber: Olahan Data Eviews versi 10, 2019

Hasil uji normalitas menunjukkan bahwa nilai Prob. JB (Jarque-Bera) > nilai a $(0,05)$ dengan nilai Probabilitas Jarque-Bera $0,428237>0,05$, sehingga dapat disimpulkan bahwa residual terdistribusi normal artinya asumsi klasik tentang kenormalan telah terpenuhi.

\section{Uji Autokorelasi}

Penelitian ini menggunakan uji DurbinWatson (D-W) untuk menguji kemungkinan autokorelasi, metode Durbin Watson ini mengasumsikan adanya first order autoregressive AR (1) dalam model.
Pada Common Effect Model dapat dilihat nilai dari metode Durbin-Watson (DW). Berikut uji autokorelasi dengan metode Durbin-Watson: Keputusan ada tidaknya gejala autokorelasi dengan membandingkan nilai Durbin-Watson (DW) hitung dengan kriteria pengujian autokorelasi (Tabel 9). Berdasarkan hasil uji autokorelasi didapati nilai Durbin-Watson stat sebesar 2,271505. Nilai lebih besar dari DU 1,54 dan lebih kecil dari 4-DU 2,46. Hal ini mem- buktikan menerima H0, berarti tidak terdapat autokorelasi pada Common Effect Model penelitian ini.

Tabel 9

Hasil Uji Autokorelasi dengan Metode Durbin-Watson (D-W)

\begin{tabular}{lrll}
\hline R-squared & 0.303713 & Mean dependent var & 28.63900 \\
Adjusted R-squared & 0.201318 & S.D. dependent var & 46.86162 \\
S.E. of regression & 41.87976 & Akaike info criterion & 10.44496 \\
Sum squared resid & 59633.08 & Schwarz criterion & 10.69830 \\
Log likelihood & -202.8993 & Hannan-Quinn criter. & 10.53656 \\
F-statistic & 2.966093 & Durbin-Watson stat & $\mathbf{2 . 2 7 1 5 0 5}$ \\
Prob(F-statistic) & 0.025070 & & \\
\hline
\end{tabular}

Sumber: Olahan Data Eviews versi 10, 2019 


\section{Uji Multikolinieritas}

Pengujian multikolinearitas, dapat dilihat matrik korelasinya. Jika masingmasing variabel bebas berkorelasi lebih besar dari 90\% maka termasuk memiliki hubungan yang tinggi atau ada indikasi multikolinearitas. Berikut matrik korelasi antara variabel bebas (independent variable):
Berdasarkan hasil dari Tabel 10 dapat dilihat masing-masing variabel bebas yaitu NPL (Non Performing Loan), LDR (Loan to Deposit Ratio), ROA (Return On Asset), NIM (Net Interest Margin), dan CAR (Capital Adequacy Ratio) berkorelasi lebih kecil dari $90 \%$, maka dapat disimpulkan tidak terdapat multikolinearitas.

Tabel 10

Matrik Korelasi Variabel Bebas

\begin{tabular}{|c|c|c|c|c|c|}
\hline & $X_{1}$ & $X_{2}$ & $X_{3}$ & $X_{4}$ & X5 \\
\hline$X_{1}$ & 1.000000 & 0.167472 & -0.692950 & -0.294099 & -0.055866 \\
\hline$X_{2}$ & 0.167472 & 1.000000 & -0.5331 & -0.319906 & 0.314913 \\
\hline$X_{3}$ & -0.692950 & -0.533107 & 1.000000 & 0.793734 & -0.107969 \\
\hline$X_{4}$ & -0.294099 & -0.319906 & 0.793734 & 1.000000 & -0.051790 \\
\hline$X_{5}$ & -0.055866 & 0.314913 & -0.107969 & -0.051790 & 1.000000 \\
\hline
\end{tabular}

\section{Uji Heteroskedastisitas}

Pengujian heteroskedastisitas bertujuan untuk menguji apakah dalam model regresi terjadi ketidaksamaan variance dari residual satu pengamatan ke pengamatan lain, jika variance dari residual satu pengamatan ke pengamatan lain berbeda maka disebut heteroskedastisitas.
Kriteria pengujiannya adalah:

$\mathrm{H}_{0}$ : Prob R.Square $>5 \%$, data tidak terjadi heteroskedastisitas

$\mathrm{H}_{1}$ : Prob R.Square < 5\%, data terjadi heteroskedastisitas

Berikut hasil uji heteroskedastisitas dengan menggunakan aplikasi Eviews:

Tabel 11

Hasil Uji Heteroskedastisitas

\begin{tabular}{lcll}
\hline \hline Heteroskedasticity Test: White & & \\
\hline F-statistic & 1.527246 & Prob. F(5,34) & 0.2074 \\
Obs*R-squared & 7.336140 & Prob. Chi-Square(5) & $\mathbf{0 . 1 9 6 8}$ \\
Scaled explained SS & 4.618818 & Prob. Chi-Square(5) & 0.4641 \\
\hline \multicolumn{4}{l}{ Sumber: Olahan Data Eviews versi 10, 2019}
\end{tabular}

Berdasarkan hasil diatas, diketahui hasil uji heteroskedastisitas menunjukkan bahwa nilai Prob. $R$-Squared $>$ nilai a $(0,05)$ dengan nilai Prob. F-statistik 0,1968 > 0,05, sehingga dapat disimpulkan bahwa $\mathrm{H}_{0}$ diterima yang artinya tidak terjadi heteroskedastisitas.

\section{Pengujian Hipotesis}

Pengujian hipotesis dalam penelitian ini mengunakan Uji t (Uji regresi secara parsil),
Uji F (Uji regresi secara simultan) dan Koefisien determinasi.

\section{Uji t (Uji Regresi secara parsial)}

Uji $t$ ini digunakan untuk melihat tingkat signifikansi dari variabel bebas secara individu dalam mempengaruhi variasi dari variabel terikat. Uji $t$ dapat dilakukan dengan melihat $t_{\text {hitung dibanding- }}$ kan dengan $t_{\text {tabel, }}$ dapat dibuat kesimpulan $\mathrm{H}_{0}$ tabel. Melalui perbandingan $t_{\text {tabel, }}$ ditolak 
yang berarti $\mathrm{H} 1$ diterima sehingga terdapat hubungan antara variabel bebas dan variabel terikat secara individu. Berikut uji $\mathrm{t}$ pada penelitian ini:

\section{Tabel 12}

\section{Hasil Pengujian Hipotesis - Uji t (Uji Regresi Secara Parsial)}

Dependent Variable: Y

Method: Panel Least Squares

Date: 12/24/19 Time: 13:29

Sample: 20092018

Periods included: 10

Cross-sections included: 4

Total panel (balanced) observations: 40

\begin{tabular}{ccccc}
\hline \hline Variable & Coefficient & Std. Error & t-Statistic & Prob. \\
\hline C & 271.6883 & 124.2869 & 2.185977 & 0.0358 \\
X1 & -0.814877 & 16.65715 & -0.048921 & $\mathbf{0 . 9 6 1 3}$ \\
X2 & -2.198016 & 0.778268 & -2.824241 & $\mathbf{0 . 0 0 7 9}$ \\
X3 & -32.14514 & 23.06376 & -1.393751 & $\mathbf{0 . 1 7 2 4}$ \\
X4 & 12.02707 & 10.46843 & 1.148890 & $\mathbf{0 . 2 5 8 6}$ \\
X5 & -1.652083 & 2.651957 & -0.622968 & $\mathbf{0 . 5 3 7 5}$ \\
\hline
\end{tabular}

Sumber: Olahan Data Eviews versi 10, 2019

Pengujian hipotesis juga dapat dilakukan dengan penggunaan konsep p-value, dengan membandingkan $p$-value dengan taraf signifikansi nilai probabilitas masingmasing variabel bebas sebesar 0,05. Berdasarkan hasil diatas dapat disimpulkan bahwa hanya variabel LDR (Loan to Deposit Ratio) yang berpengaruh signifikan terhadap return saham dikarenakan nilai probabilitasnya kurang dari 0,05 yaitu sebesar 0,0079.

\section{Uji F (Uji Regresi secara simultan)}

Pengujian F (Uji Regresi secara simultan) dihitung berdasarkan perbandingan antara nilai tingkat signifikansi (a tertentu) dengan nilai prob. F statisitik. Kriteria menerima atau menolaknya ditentukan oleh seberapa besar nilai signifikansinya. Penelitian ini menggunakan signifikan pada tingkat signifikansi 5\%. Perhitungan signifikansi dapat dilakukan dengan membandingkan antara nilai signifikansi $(0,05)$ dengan nilai probabilitas F-statistik, dimana nilai probabilitas F-statistik sebesar 0,025070. Berdasarkan Tabel 13, dapat disimpulkan seluruh variabel bebas secara simultan berpengaruh terhadap return saham.

Tabel 13

Hasil Pengujian Hipotesis - Uji F (Uji Regresi Secara Simultan)

\begin{tabular}{lrll}
\hline R-squared & 0.303713 & Mean dependent var & 28.63900 \\
Adjusted R-squared & 0.201318 & S.D. dependent var & 46.86162 \\
S.E. of regression & 41.87976 & Akaike info criterion & 10.44496 \\
Sum squared resid & 59633.08 & Schwarz criterion & 10.69830 \\
Log likelihood & -202.8993 & Hannan-Quinn criter. & 10.53656 \\
F-statistic & $\mathbf{2 . 9 6 6 0 9 3}$ & Durbin-Watson stat & 2.271505 \\
Prob(F-statistic) & $\mathbf{0 . 0 2 5 0 7 0}$ & & \\
\hline
\end{tabular}

Sumber: Olahan Data Eviews versi 10, 2019 
Uji $F$ juga dapat dilakukan dengan melihat $F_{\text {hitung }}$ dibandingkan dengan $F_{\text {tabel. }} F_{\text {hitung }}$ berdasarkan Tabel 13 sebesar 2,966093, kemudian $\mathrm{F}_{\text {tabel }}$ sebesar 2,49.

Dengan demikian dapat disimpulkan seluruh variabel bebas secara simultan berpengaruh terhadap return saham pada bank BUMN periode 2009-2018 (2,966093> $2,49)$.

\section{Koefisien Determinasi}

Berikut hasil pengujian yang menujukkan koefisien determinasi pada penelitian ini:

Tabel 14

Hasil Pengujian Hipotesis - Koefisien Determinasi

\begin{tabular}{lrll}
\hline \hline R-squared & $\mathbf{0 . 3 0 3 7 1 3}$ & Mean dependent var & 28.63900 \\
Adjusted R-squared & $\mathbf{0 . 2 0 1 3 1 8}$ & S.D. dependent var & 46.86162 \\
S.E. of regression & 41.87976 & Akaike info criterion & 10.44496 \\
Sum squared resid & 59633.08 & Schwarz criterion & 10.69830 \\
Log likelihood & -202.8993 & Hannan-Quinn criter. & 10.53656 \\
F-statistic & 2.966093 & Durbin-Watson stat & 2.271505 \\
Prob(F-statistic) & 0.025070 & & \\
\hline
\end{tabular}

Sumber: Olahan Data Eviews versi 10, 2019

Berdasarkan hasil dari Tabel 14 dapat diketahui variasi total pengaruh variabelvariabel bebas terhadap variabel terikatnya (return saham) adalah sebesar 30,37\%, sisanya sebesar $69,63 \%$ dipengaruhi oleh variabel lain yang tidak diteliti dalam penelitian ini.

\section{Pembahasan}

Pengaruh Tingkat Kesehatan Bank Terhadap Return Saham

Penelitian ini bertujuan untuk mengetahui ada atau tidaknya pengaruh tingkat kesehatan bank yang terdiri dari NPL (Non Performing Loan), LDR (Loan to Deposit rasio), ROA (Return On Asset), NIM (Net Interest Margin) dan CAR (Capital Adequacy Ratio) baik secara parsial maupun simultan terhadap return saham Bank BUMN Periode 2009-2018.

\section{Pengaruh Rasio NPL (Non Performing Loan) Terhadap Return Saham}

Rasio NPL (Non Performing Loan) adalah seluruh kredit pada pihak ketiga dengan kolektibilitas kurang lancar, diragukan dan macet dibandingkan dengan total kredit. Semakin kecil hasil rasio NPL (Non performing Loan), maka tingkat kualitas kredit bank semakin baik. Hal tersebut mencerminkan kondisi 4 (empat) Bank BUMN yang dinilai mampu mengahapi perubahan yang signifikan dari bisnis bank. (Hafidhin et al., 2018; Wijaya, 2018). Berdasarkan hasil uji penelitian ini pengaruh tingkat kesehatan bank dengan menggunakan rasio NPL (Non performing Loan) terhadap return saham, membuktikan bahwa rasio NPL (Non performing Loan) tidak berpengaruh signifikan terhadap return saham dikarenakan nilai probilitasnya sebesar $0,9613>0,05$. Hal ini diidentifikasi karena bahwa para investor tidak terlalu memperhatikan aspek pengelolaan kualitas kredit bank, dikarenakan selama rasio NPL (Non performing Loan) masih dibawah ketentuan regulasi yaitu 5\%. Oleh karena itu, rasio NPL (Non performing Loan) tidak berpengaruh signifikan terhadap return saham pada bank BUMN periode 2009-2018. Hal ini sejalan dengan penelitian Naftali et al. (2018: 2498) bahwa Risk Profile tidak berpengaruh signifikan terhadap Harga Saham. Meskipun kondisi Bank BUMN mendapat predikat cukup sehat (Wijaya, 2018), dalam penelitian ini variabel risk 
Profile yang sehat tidak dapat mempengaruhi return saham, dapat dikatakan investor tidak mempertimbangkan risk Profile dalam pengambilan keputusan berinvestasi.

\section{Pengaruh Rasio LDR (Loan to Deposit Ratio) Terhadap Return Saham}

Rasio LDR (Loan to Deposit Ratio) memberikan indikasi bagaimana struktur deposit dari bank mendanai portofolio kredit bank. Semakin besar rasio LDR, artinya likuiditas bank semakin bergantung pada sumber dana non-deposit. Mengingat likuiditas bank lebih ditentukan oleh kondisi operasional, permodalan, kondisi sistem keuangan, dan makroekonomi Wuryandani et al. (2014:264). Berdasarkan hasil uji penelitian ini pengaruh tingkat kesehatan bank dengan menggunakan rasio LDR (Loan to Deposit Ratio) terhadap return saham, membuktikan bahwa rasio LDR (Loan to Deposit Ratio) pada penelitian ini berpengaruh signifikan terhadap return saham dikarenakan nilai probabilitasnya kurang dari 0,05 yaitu sebesar 0,0079. Hal ini diidentifikasi karena kemampuan bank BUMN ketika melunasi kewajiban yang sudah jatuh tempo. Penggunaan dana pihak ketiga yang sangat optimal, dikarenakan rasio LDR (Loan to Deposit Ratio) yang telah diatur oleh regulator membuat kondisi bank BUMN terjaga likuiditasnya.

Hal ini didukung dengan penelitian Subandi dan Ghozali (2013: 133) menyatakan bahwa variabel yang mempengaruhi kinerja profitabilitas ROA perbankan konvensional adalah LDR. Kemampuan perbankan dalam mendapatkan keuntungan, salah satunya adalah pengolahan likuiditas. Sehingga LDR (Loan to Deposit Ratio) dapat dipertimbangkan investor dalam pengambilan keputusan berinvestasi di saham perbankan.

Namun hasil penelitian ini tidak sejalan dengan penelitian Uzliawati et al. (2014: 201) menyatakan bahwa likuiditas perbankan yang terdaftar di BEI tidak terlalu dipertimbangkan pihak eksternal perusahaan dalam melakukan penilaian sebuah perbankan. Sehingga likuiditas tidak memiliki pengaruh terhadap nilai perusahaan perbankan. Sementara dari penelitian ini, investor mempetimbangkan pengambilan keputusan investasinya dari nilai perusahaan perbankan yaitu rasio LDR (Loan to Deposit Ratio).

\section{Pengaruh Rasio ROA (Return On Asset) Terhadap Return Saham}

Rasio ROA (Return On Assets), laba bersih dibagi rata-rata total aset, merupakan rasio yang sering digunakan untuk mengukur kinerja bank. ROA tergantung pada kemampuan bank untuk memperoleh pendapatan bunga, pengendalian biaya bunga dan efisiensi operasional dan lainnya. Berdasarkan hasil uji penelitian ini pengaruh tingkat kesehatan bank dengan menggunakan rasio ROA (Return On Assets) terhadap return saham, membuktikan bahwa pada penelitian ini rasio ROA (Return On Assets) tidak berpengaruh signifikan terhadap return saham dikarenakan nilai probabilitasnya lebih besar dari 0,05 yaitu sebesar 0,1724. Hal ini diidentifikasi karena faktor yang mempengaruhi return saham bukan hanya earning dengan dimensi variabel rasio ROA (Return On Assets), namun jika dilihat dari perolehan rasio ROA (Return On Assets) selama periode 2009-2018 tidak pernah mengalami kerugian, sejalan dengan penelitian Widyanigrum et al. (2014: 1) menyatakan bahwa Return On Asset menunjukkan masih terdapat bank yang tidak sehat dengan nilai Return On Asset di bawah 1,25\%, salah satu Bank BUMN yang pernah mengalaminya adalah PT. Bank Tabungan Negara Tbk pada tahun 2014 nilai perolehan hanya 1,12\%. Dalam penelitian ini rasio ROA (Return On Assets) tidak berpengaruh signifikan terhadap return saham pada bank BUMN periode 2009-2018.

Variabel profitabilitas berpengaruh positif dan signifikan terhadap nilai perusahaan. (Hermuningsih, 2013; Kellen, 2011), sejalan dengan penelitian Pradana 
dan Sanjaya (2017: 122) yang menyatakan bahwa profitabilitas merupakan variabel utama yang masuk dalam pertimbangan RUPS untuk menentukan keputusan pembagian dividen tunai. Semakin tinggi profitabilitas (ROA), semakin besar pula probabilitas perbankan akan membagikan dividen tunai, serta penelitian Suhardjanto dan Dewi (2011: 115) mendukung variabel profitabilitas yang mencukupi menjadikan perusahaan mendapatkan keuntungan positif, yaitu mendapatkan kepercayaan dari masyarakat yang pada akhirnya akan berdampak meningkatnya keuntungan perusahaan di masa yang akan datang, maka dapat disimpulkan kembali investor dalam pengambilan keputusan investasi tidak melihat variabel nilai perusahaan dan pembagian deviden tunai, karena variabel profitabitas dalam penelitian ini tidak mempengaruhi return saham.

\section{Pengaruh Rasio NIM (Net Interest Margin) Terhadap Return Saham}

Rasio NIM (Net Interest Margin) merupakan pendapatan bunga dari kredit, investasi, dikurangi biaya dana deposito, tabungan dan sebagainya yang disebut dengan Net Interest Income (NII), dibagai dengan rata-rata baik debit aktiva produktif. Berdasarkan hasil uji penelitian ini pengaruh tingkat kesehatan bank dengan menggunakan rasio NIM (Net Interest Margin) terhadap return saham, membuktikan bahwa pada penelitian ini rasio NIM (Net Interest Margin) tidak berpengaruh signifikan terhadap return saham dikarenakan nilai probabilitasnya lebih besar dari 0,05 yaitu sebesar 0,2586 . Hal ini diidentifikasi karena faktor yang mempengaruhi return saham bukan hanya earning dengan dimensi variabel rasio NIM (Net Interest Margin). Berdasarkan data selama periode 2009-2018 terdapat penurunan rasio tingkat kesehatan bank dikarenakan perubahan suku bunga acuan yang dikeluarkan Bank Indonesia. Hal ini dikarenakan rasio NIM (Net Interest Margin) bergantung pada sensitivitas dari komposisi aktiva bank terhadap perubahan suku bunga. Hal ini tidak sejalan dengan penelitian Wuryandani et al. (2014:264) menyatakan bahwa kurang kuatnya pengaruh kebijakan moneter, mengindikasikan bahwa Bank Indonesia tidak perlu menyerap likuiditas melalui suku bunga Bank Indonesia yang tinggi, mengingat likuiditas bank lebih ditentukan oleh kondisi operasional, permodalan, kondisi sistem keuangan, dan makro ekonomi.

\section{Pengaruh Rasio CAR (Capital Adequacy} Ratio) Terhadap Return Saham

Rasio CAR (Capital Adequacy Ratio), dimana jumlah dikaitkan dengan risiko kredit pada aset pada neraca bank, CAR diharuskan lebih dari 8\%. Rasio CAR (Capital Adequacy Ratio) juga dikenal sebagai rasio kecukupan modal untuk mengatasi kemungkinan risiko kerugian, mengukur kemampuan suatu perbankan dan asetnya. Secara keseluruhan setiap bank memiliki nilai Capital Adequacy Ratio di atas 10\% sehingga masuk ke dalam kategori bank sehat. (Widyaningrum et al., 2014; Paputungan, 2016). Berdasarkan hasil uji penelitian ini pengaruh tingkat kesehatan bank dengan menggunakan rasio CAR (Capital Adequacy Ratio) terhadap return saham, membuktikan bahwa pada penelitian ini rasio CAR (Capital Adequacy Ratio) tidak berpengaruh signifikan terhadap return saham dikarenakan nilai probabilitasnya lebih besar dari 0,05 yaitu sebesar 0,5375. Hal ini diidentifikasi karena rasio CAR (Capital Adequacy Ratio) terlalu tinggi, sehingga penggunaan modal untuk perolehan laba tidak maksimal. Hal ini sejalan dengan penelitian Ahmad (2015) menyatakan bahwa CAR (Capital Adequacy Ratio) memiliki pengaruh negatif namun tidak signifikan terhadap ROA.

\section{SIMPULAN DAN SARAN Simpulan}

Berdasarkan hasil penelitian pengaruh tingkat kesehatan bank yang terdiri dari 
NPL (Non Performing Loan), LDR (Loan to Deposit Ratio), ROA (Return On Asset), NIM (Net Interest Margin) dan CAR (Capital Adequacy Ratio) terhadap return saham. Penelitian dilakukan pada bank BUMN yang terdaftar di Bursa Efek Indonesia (BEI) periode 2009-2018, sehingga dapat disimpulkan sebagai berikut: (1). Berdasarkan hasil analisis deskriptif selama periode 2009-2018 menunjukkan bahwa perkembangan tingkat kesehatan bank jika dilihat dari rata-rata dari masing-masing variabel yaitu: NPL (Non Performing Loan), LDR (Loan to Deposit Rasio), ROA (Return On Asset), NIM (Net Interest Margin) dan CAR (Capital Adequacy Ratio) telah sesuai dengan ketentuan Bank Indonesia, sehingga bank BUMN dapat menjaga tingkat kesehatan bank masing-masing bank. (2). Berdasarkan hasil analisis deskriptif selama periode 2009-2018 menunjukkan bahwa perkembangan return saham pada bank BUMN masih bisa menutupi kenaikan inflasi selama 10 tahun terakhir, jika dibandingkan dengan rata-rata return saham yang dihasilkan bank BUMN. (3). Berdasarkan hasil analisis asosiatif selama periode 2009-2018 menunjukkan bahwa pengaruh tingkat kesehatan bank terhadap return saham pada bank BUMN secara parsial, hanya LDR (Loan to Deposit Ratio) yang berpengaruh signifikan terhadap return saham sedangkan NPL (Non Performing Loan), ROA (Return On Asset), NIM (Net Interest Margin) dan CAR (Capital Adequacy Ratio) tidak berpengaruh signifikan terhadap return saham. Pengaruh tingkat kesehatan bank terhadap return saham pada bank BUMN secara simultan seluruh variabel bebas secara simultan berpengaruh terhadap return saham pada bank BUMN.

\section{Saran}

Berdasarkan simpulan dari hasil penelitian, terdapat beberapa saran yang mungkin berguna bagi pihak investor serta bagi penelitian selanjutnya: (1). Saran yang dapat diberikan kepada investor, pada saat melakukan investasi di pasar modal se- baiknya melakukan analisis teknik fundamental melalui kinerja laporan keuangan perusahaan kemudian dibandingkan dengan tingkat return saham perusahaan tersebut. Saran yang dapat diberikan kepada penelitian selanjutnya, apabila melakukan penelitian yang sama dengan penelitian ini sebaiknya menambah dimensi variabel tingkat kesehatan bank, serta menambahkan atau menggunakan data kuartal atau bulanan, agar hasil yang didapat lebih akurat.

\section{DAFTAR PUSTAKA}

Ahmad, G. N. 2015. Determinan Profitabilitas Bank: Studi Kasus Pada Bank Pembangunan Daerah. Jurnal Keuangan dan Perbankan 19(3): 431-438.

Dewi, G. A. K. R. S. dan D. Prameswari. 2018. Investasi dan Pasar Modal Indonesia. PT Raja Grafindo Persada. Depok.

Hafidhin, R., S. M. Rahayu, dan Zahroh. 2018. Analisis Tingkat Kesehatan Bank Dengan Menggunakan Metode Risk Profile, Earnings and Capital. Jurnal Administrasi Bisnis (JAB) 57(2): 116-125.

Hermunigsih, S. 2013. Pengaruh Profitabilitas, Growth opportunity, sruktur Modal terhadap nilai Perusahaan Pada Perusahaan Publik di Indonesia. Journal Bulletin of Monetary Economics And Banking 16(2): 127-148.

Ikatan Bankir Indonesia. 2016. Manajemen Kesehatan Bank Berbasis Risko. Gramedia Pustaka Utama. Jakarta.

Kellen, P. B. 2011. Struktur Kepemilikan, Profitabilitas Dan Risiko Perusahaan Terhadap Struktur Modal Dan Nilai Perusahaan. Jurnal Keuangan dan Perbankan 15(1): 201-212.

Naftali, S. C., I. S. Saerang, dan J. E. Tulung. 2018. Pengaruh Tingkat Kesehatan Bank Terhadap Harga Saham Perbankan Yang Terdaftar di Bursa Efek Indonesia Periode 2012-2016. Jurnal EMBA 6(4): 2498-2507.

Otoritas Jasa Keuangan. 2016. Peraturan Otoritas Jasa Keuangan nomor 4/ 
POJK.03/2016 tentang Penilaian Tingkat Kesehatan Bank Umum.

https://www.ojk.go.id/id/kanal/perbankan/r egulasi/peraturan-ojk/Pages/pojk-tentangpenilaian-tingkat-kesehatan-bank-umum. aspx. Diakses tanggal 17 Oktober 2019.

Paputungan, D. F. 2016. Penilaian Tingkat Kesehatan Bank Menggunakan Metode CAMEL Pada PT. Bank Rakyat Indonesia Cabang Manado Periode 20102015. Jurnal EMBA 4(3): 729-740.

Pradana, S. W. L. dan I. P. S. Sanjaya. 2017. Dampak Profitailitas, Aliran Kas Bebas, Dan Kesempatan Investasi Terhadap Pembayaran Dividen Perusahaan Perbankan. Jurnal Keuangan dan Perbankan 21(3): 113-124.

Subandi dan I. Ghozali. 2013. Determinasi Efisiensi Dan Dampaknya Terhadap Kinerja Profitabilitas Industri Perbankan di Indonesia. Jurnal Keuangan dan Perbankan 17(1): 123-135.

Suhardjanto, D. dan A. Dewi. 2011. Pengungkapan Risiko Finansial Dan Tata Kelola Perusahaan: Studi Empiris Perbankan Indonesia. Jurnal Keuangan dan Perbankan 15(1): 105-118.
Uzliawati, L., N. Nofianti, dan D. P. Ratnasari. 2016. Struktur Modal, Investment Opportunity Set, Likuiditas Dan Nilai Perusahaan. Jurnal Keuangan dan Perbankan 20(2): 195-203.

Widyanigrum, H. A., Suhadak, dan Topowijono. 2014. Analisis Tingkat Kesehatan Bank Dengan Menggunakan Metode Risk-Based Bank Rating (RBBR) (Studi pada Bank yang Terdaftar di Bursa Efek Indonesia dalam IHSG Sub Sektor Perbankan Tahun 2012). Jurnal Administrasi Bisnis (JAB) 9(2): 1-9.

Wijaya, B. 2018. Analisis Tingkat Kesehatan Bank Dengan Menggunakan Metode Risk-Based Bank Rating (RBBR) (Studi Pada Bank Yang Termasuk Saham LQ45 Sub Sektor Perbankan Tahun 2010-2016). Jurnal Akuntansi Maranatha 10(1): 85-97.

Wuryandani, G., R. Ginting, D. Iskandar, dan Z. Sitompul. 2014. Pengelolaan Dana Dan Likuiditas Bank.Journal Bulletin of Monetary Economics And Banking 16(3): 247-276. 